\title{
Conclusions and Recommendations
}

\begin{abstract}
The political context of religious freedom law enforcement in health care settings, in addition to hateful rhetoric and physical violence against transgender people, requires health care employees, specifically hospital chaplains and educators, to expand their traditional roles from bedside spiritual companions to practical public theologians. This expansion includes shocking the hospital system that has become "chilled" by religious freedom enforcement, becoming literate about religious freedom law, becoming active lobbyist against discrimination in the name of religious freedom, and becoming culturally competent. Buddhist-Christian dialogue can inspire and support the womb visualization practices and Buddhist gathas in the Thich Nhat Hanh tradition. It is recommended that chaplains and spiritual care professionals implement the practical and trans-culturally-specific instructions called "Special Considerations for Pastoral Care in Health Care Settings" by consultants Bradley and Metrick of Elements Consulting.
\end{abstract}

Keywords Clinical Pastoral Education • Elements Consulting • Gathas - Jake Bradley • Nate Metrick • Thich Nhat Hanh 
The US transgender community remains vulnerable as long as the religious freedom to discriminate is protected by the US government. Chaplains, pastoral counselors, and spiritual caregivers, many of whom work in public hospitals that serve transgender citizens have an opportunity to shift the national conversation from the right to religious discrimination to the responsible exercise of religious freedom. It appears, however, that pastoral and spiritual care professionals are not yet literate enough in religious freedom law, to effectively advocate for responsible religious freedom practices. Religious freedom law education for chaplains in seminaries, divinity schools, and Clinical Pastoral Education can ameliorate this deficit, and, if warranted, organizations like Human Rights Campaign can add spiritual care departments to their indexes for locating quality spiritual care for transgender patients.

Public hospital chaplaincy departments are largely led by chaplains affiliated with Protestant-Christian traditions, but Buddhists are emerging in the fields of clinical pastoral and spiritual care. Given the interreligious nature of Clinical Pastoral Education, more Christians and Buddhists are working together for the benefit of those in health care treatment. Buddhist practitioners willing to engage in Lady Mahamaya-inspired visualization practices such as Mystical Transcendental Transsexuality, creating the conditions for experiencing Relative Realm Gender Fluidity, may offer their Christian interreligious dialogue partners practices that can inform St. Paul's nongendered Christ consciousness and transform hatred against trans people into love of their kin. Their interreligious dialogues can include topics related to Paul O. Ingram's four-part framework of Conceptual Dialogue, Conceptual Dialogue with the Natural Sciences, Buddhist-Christian Socially Engaged Dialogue, and Buddhist-Christian Interior Dialogue. I am suggesting that the Buddhist-Christian dialogue within spiritual care clinical contexts also include law, psychology, government, and religious anthropology. Why increase the complexity of already complicated conversations? Because a society that is hostile toward transgender people contributes to depression, anxiety, suicidal ideation, suicides, and violence against our trans kin. Thich Nhat Hanh's unique Buddhist teachings have much to offer Christians, especially his discussions of Lady Mahamaya. I call his visualization practice a Mystical Transcendental Transsexuality that promotes Relative Realm Gender Fluidity. Christians who believe, as St. Paul believed, that in Christ there is no male or female, may appreciate visualization practices that allow binary gender constructs to dissolve into Christ-consciousness in the here and 
now. Our bodies do not radically change through this practice, but our gendered self-concepts may loosen, potentially expanding our ability to empathize with transgender patients, or trans chaplains with cisgender patients. Mindfulness of the body should include the remembrance that we all have a unique blend of hormones and chromosomes and that hormonal changes occur throughout our lives, changing our experiences of feeling "male" or "female."

The ability to empathize will be the power that drives chaplains toward being in political solidarity with transgender patients and shocking the hospital system into returning to its roots in hospitality. Radical Dharma solidarity as practiced by queer African-American Buddhists williams, Owens, and Syedullah, combined with the movements and practices of Gill-Austern's Christianity, can go a long way toward transforming hospital culture from the inside out. The shock is not intended to feel good; the objective is to offer something radical and immediate such that new life is given to the dying. What are some practical steps spiritual caregivers can take to provide hospitality to those targeted by our legal and political systems? Think of the Parable of the Good Samaritan as The Parable of Our Collective Survival.

The Parable of Our Collective Survival involves four people. In this parable, we learn that the priest (who I call the anointed) sees the vulnerable man and keeps walking. The Levite (who I call the pious) also sees the vulnerable man and keeps walking. It is surprising to think that those who are considered spiritually pure would be the ones who would act heinously toward the vulnerable by depriving them of mercy, but that is exactly what religious freedom to discriminate laws attempt to do. These laws provide a legislative mechanism for the anointed and pious to organize themselves against a perpetually despised and vulnerable group of people. The Parable of Our Collective Survival teaches us that the Samaritan (who I call the despised) and the helpless (who I call the vulnerable) teach the anointed and the pious what it means to live according to higher purposes. Higher purposes, beyond being a good neighbor to one vulnerable person at a time, ensure our collective survival through the process of mutually desegregating civilization. Mutually desegregating civilization is when the despised responds to the vulnerable out of compassion and mercy despite the negative labels each have carried, and the vulnerable allows the despised to be who they truly are-responsive to others' needs-and accepts their compassion and mercy. When Jesus tells the lawyer to do as the Samaritan did, he is inculcating in the lawyer the capacity to give birth to the 
bodhisattvas and buddhas within himself and those in need. Herein lies a microcosmic example of the macrocosmic existential situation we all share.

In the late 1980s, I was visiting my cousin Damon (not his real name) in California. He was engaged to be married to Lois (not her real name) who seemed very kind and engaging. We were talking about the earthquake we had experienced the previous night. Lois told us about a time when an earthquake hit while she was working in her office. As the earth shook, Lois and her two male colleagues ran to their designated safe place and held hands underneath a desk as they feared for their lives. Lois lamented, while telling the story, that on what might have been her last day on earth, she was holding hands with a gay man and an atheist. She wondered how God could have put her, a good Christian, in that position. Lois, the pious and also vulnerable, could not bear the thought that the despised (who were also vulnerable) had comforted her (the pious) in her vulnerability. To be comforted in our vulnerability is the path to salvation. Let's tell The Parable in a way that inspires all people to see that they are part of the collective and are all vulnerable thus must care for the collective, and be cared for by the collective, in order to survive as civilized human beings.

With the introduction of the Department of Health and Human Services Office for Civil Rights Conscience and Religious Freedom Division (CRFD) subjecting vulnerable hospital patients to discrimination on religious grounds through the threat and potential loss of hundreds of millions of dollars to hospitals, chaplains must become more aware of religious freedom laws in order to protect themselves, their colleagues, patients, and the public health care institutions they serve.

Clinical Pastoral Education (CPE) programs are at risk. First, their application for interns and residents does not clearly state in writing that $\mathrm{CPE}$ involves intense and prolonged interreligious dialogue on spiritual care matters. Second, the application does not have an alternative dispute clause. With the reality of CRFD, an alternative dispute clause could serve to put the applicant on notice that interreligious disputes on care within the bioethical domain of a hospital will be resolved within the hospital. I am making the argument that although the First Amendment applies to all US citizens, because our reality is interreligious cohabitation, the patient's care in the hospital, not an employee's exercise of religious freedom, is the priority. Places of worship are where one's exercise of religious freedom is the priority. Keeping public hospitals in mind, with patient care as the priority over the exercise of religious freedom, especially the religious 
freedom to discriminate, public hospitals (and other health care organizations) are the places where we enact mutually desegregating civilization. Is there anything the despised and the vulnerable, in relationship with one another, can do to invite the anointed and the pious into the process of mutually desegregating civilization?

The despised and the vulnerable can teach us how to disobey, resist, and transform oppressive laws. They can show us how to make economic systems more transparent and participatory, revive humanism in religion, and intentionally moderate our desires in order to make room for another's desires to manifest. We learn how to cohabitate.

Sullivan says,

Today CPE has no particular expressed religious identity, focusing rather on the praxis-oriented professional development of the minister of any tradition-or none. CPE care is theorized using a fusion of the student's own theological tradition, behavioral and social scientific knowledge and methods, and a "multicultural" perspective of respect founded in popular constitutional ideas. ${ }^{1}$

Sullivan does not state what the constitutional ideas are, but my 2018 research with chaplain educators hints that these constitutional ideas may be freedom and equality. Survey responses demonstrated a high literacy rate regarding the First Amendment and a high rate of tolerance for difference. Chaplain educators draw on a variety of resources to help their interns and residents cultivate compassion for those outside each student's religious group, including the intern's or resident's own religious traditions and practices, the US Constitution, chaplaincy organization's professional code of ethics, their own values, professional standards of care, hospital expectations, and other resources. When asked, "How do you cultivate compassion for those outside your religious group?" chaplain educators answered, advocacy, ethical commitments, meditation, prayer, selfless service, and a list of other methods. Though it appears that chaplain educators value freedom and equality, two constitutional ideas consistent with the universality of the "ministry of presence," chaplain educators tend not to talk with their students about the First and Fourteenth Amendments. Their methods for cultivating compassion do not include a reading of the US Constitution, in whole or in part.

If these surveys are an indication that spiritual care professionals throughout the United States are largely unaware of laws and legislative 
processes and not inclined to offer their expertise to legislators, care professions should examine the perils to them and those they serve and decide whether or not becoming politically involved should be a part of what it means to be a spiritual care professional. Can we take what works in private and make a civilizing impact publicly? It is time for chaplains to come out of the closet!

I believe Buddhists and Christians work well together in chaplaincy situations because we have shared values in personal transformation away from the compulsions and habits of self-gratification and toward selfless service. Christians teach the values of justice seeking and advocacy; Buddhists train in the understanding of no self and practices of exchanging self for other. Christians and Buddhists have much to offer one another.

Thich Nhat Hanh encourages people wanting to live mindful lives to practice the gathas he learned when he first entered monastic life, gathas derived from the Avatamsaka Sutra. Nhat Hanh says, "When I wrote the gathas for using the telephone, driving a car, and turning on the computer, I did so within the tradition that I inherited from my teachers. You are now one of the inheritors of this tradition. Composing your own gathas to fit the specific circumstances of your life is one wonderful way to practice mindfulness." 2 Unlike the teen-aged Nhat Hanh, I was 40 years old when I first encountered Buddhism and Nhat Hanh's special flavor of it. I am one of the inheritors of that tradition. Now, 18 years later, I have composed my own gathas to fit the specific circumstances of our transcleansing, hospital-as-site-for-discrimination culture under the TrumpPence administration.

\section{Gathas for Spiritual Care for Hospitalized Transgender Patients}

\section{On the Morning of the Workday}

As I awaken

coming to my senses that I am still alive

I dedicate this day to the well-being of all I encounter

\section{Entering the Hospital}

Mindfully walking into the hospital

I smile to all I meet 
Dedicating my compassionate energy

For the transformation of suffering

Preparing to Meet the Transgender Patient

Mindful of my body

I breathe in to relax my body

I breathe out to relax my body

To bring a calm presence to those in need

\section{Mindful of My Body}

Mindful of my body

I know I am not my body

Mindful of my bodily forms

I know that all forms are empty and impermanent

\section{Visualizing Lady Mabamaya}

Visualizing Lady Mahamaya

I have the capacity to birth buddhas and bodhisattvas

With this spaciousness

I believe we can awaken together

\section{Greeting the Patient}

Mindful of our surroundings

I assess if conditions are comfortable for them

Seeing the patient

I say hello and tell the patient I come with well wishes for their health

\section{Asking the Patient What They Need}

Mindful of my mind

I search for an agenda

Finding an agenda, I drop it

I open, like a flower, to what the patient needs 


\section{Asking for Permission from the Patient}

Listening deeply to the patient's need

I reflect on myself as a generous resource

If I have the ability to give

I ask the patient if they want to receive

\section{Bringing the Love of a Parent}

Aware of the mystical teachings of no birth and no death

I refrain from imposing these beliefs on others

Like a loving parent would

I celebrate the new birth of this patient

\section{Embodying Hospitality}

Aware of the deluded politics of discrimination

I bring non-dual consciousness to bear

Embodying Indra's Net

We reflect each other's light

\section{Checking Connection}

Conscious of our mystical interdependence and interpenetration

I know not everyone believes or feels this connection

Checking in with the patient

I connect with them where they are

\section{Taking Leave}

Mindful of being hospitable

I remember I am also their guest

I greet with open arms and

I leave with palms together (as in, with a mind of prayerfulness and gratitude)

I believe practicing "Gathas for Spiritual Care for Hospitalized Transgender Patients" can go a long way toward transforming our biases, prejudices, and even transphobia, but chaplains also need the practical advice that already comes from the best practices for caring for 
transgender patients. Nate Metrick and Jake Bradley of Elements Consulting (team@elementsconsulting.org) have compiled a list of best practices they call "Special Considerations for Pastoral Care in Health Care Settings." Some of those special considerations include:

- Don't ask specifics about a person's body or medical history related to gender. Don't make assumptions about a person's body parts.

- Be especially sensitive if someone is having treatment for, or concerns around, a health issue that is seen as gender-related. If it becomes necessary to refer to someone's body parts that are often gendered, ask people what names they use for their body parts, and encourage other caregivers to use those (if the person is comfortable having you talk to other caregivers about that). Use gender-neutral language for body parts as often as possible (e.g., refer to someone's "chest" or "crotch").

- Be sensitive to someone's potential needs for additional privacy and modesty. Offer extra blankets or an extra layer of gowns or pajamas.

- Advocate for trans people to retain access to and use of their appearance-related items such as wigs and prosthetics. These are not luxuries or vanity materials. They are often needed for a person to feel safe in their body and to be themselves.

- If someone comes out to you, ask how they'd like you to handle that information. Don't assume that their medical staff do or don't know. Ask which family members and friends who might visit or whom you might encounter are aware.

- Ask how they want to be referred to in front of others. Know that a person's needs could vary for different people and contexts, and this is about their choice and safety!

- Don't out anyone, ever!

- Offer to support a person in coming out to or stating their needs to medical staff or friends and family. Offer to be present with them if they are intimidated by other staff or visitors.

As it relates to faith/religious/spiritual concerns, Bradley and Metrick suggest:

- Ensure that transgender people have access to rituals and rites of passage for their religion or faith path (baby blessings, bar/bat mitzvah, coming of age ceremonies, etc.) that are not gendered, or which affirm their gender self-identity. 
- Be aware of faith communities and other pastoral care providers who can be counted on to be affirming, safe, and respectful.

- Be aware of the various kinds of abuse and alienation some LGBTQ people have experienced from religion, and be prepared to help someone process that or find them a trustworthy clergy person who can.

- Don't advise someone to stick with the body that God gave them, or that they need to learn to accept their body or the gender they were assigned at birth.

Other important considerations include:

- Seek to see and understand all the different aspects of identity (gender, race, sexuality, faith, etc.) and oppression (racism, sexism, ableism, heterosexism, etc.), and how different forms of identity, oppression, and privilege intersect with each other. (In other words, a person's gender or gender status does not "trump" all the other parts of their identity - they are a whole person, whose various identities all inform each other and co-create each other. Keep in mind, for instance, that gender is raced and race is gendered-that the concept of each thing and how it is perceived and expressed is informed by the other.)

- Don't make excuses for your ignorance, or your failure to understand a person or treat them with respect and compassion. (Apologize if you've hurt someone's feelings, and ask what you can do to be safer for them.)

- Don't expect one trans person to represent an entire group of people. (e.g., don't ask one trans student to account for the whole trans community. If you're asking a question, know that you're asking them about themselves only.)

- Be honest about what you know and what you don't. Do your own education. Practice with people to gain better skills.

- Join with other allies, and seek support and feedback, and hold each other accountable.

The cultivation of mindfulness through writing and practicing gathas, coupled with the embrace of best practices, helps create safe and hospitable places for people to heal. As Bradley and Metrick have suggested, let's not make excuses for our ignorance, or our failure to understand, or our failure to treat people with respect and compassion. Pichette, Bradley, and Metrick 
are experts on religious experience and spiritual care for trans people. Attacks against trans people continue. Our governmental systems of checks and balances are being undermined, and the clarion call for "religious freedom" (ironically in one of the most religiously free countries on the planet), is an opportunity for wise resistance to tyranny and solidarity with trans people who are oppressed by our federal and state governments. Professor, activist, and TV host Melissa Harris-Perry, a theologically-educated political scientist informed by feminist and womanist scholars, demonstrates how the integration of theological and political academic disciplines can be applied to a liberatory public theological-political discourse. She is an inspiring and fierce example of how chaplains can publicly advocate for transgender people. Chaplains need to know more about religious freedom laws to avoid being agents of tyranny so that we become public practical theologians advocating for freedom from tyranny. If Sullivan is right about the role of chaplains and our practices in presence and universality, let's be bold and share with others how we live authentically while simultaneously bracketing our beliefs while we promote civilized living. If we come out of our closets of relative safety and risk shocking systems from the chilling effect of fear, applying williams, Owens, Syedullah, and Gill-Austern, we do our part in this world in a bigger and bolder way. This is how we can best be in solidarity with the transgender community. Spiritual formation through chaplaincy training, Nhat Hanh Lady Mahamaya-inspired Mystical Transcendental Transexuality that promotes Relative Realm Gender Fluidity, something akin to St. Paul's nongendered heaven, and BuddhistChristian dialogue holds promise for the deepening of empathy for our capacities to at least temporarily alter our concepts of fixed gender identities and capacities. Chaplains are no longer just prayer partners; we are becoming the ministers oppressed people can count on to create safe spaces through becoming religious freedom law literate, shocking the hospital system when necessary, re-imagining parables to include the collective, using visualization to loosen the grip of overidentifying with gender constructs, being in solidarity with the oppressed, and thereby creating safe spaces through collective engagement with the political process.

Postscript. At the time of writing (April 8, 2020), President Trump's impeachment retaliation, even though he was acquitted, is being felt. In the midst of the COVID-19 crisis, he fired the inspector general responsible for shining light on the whistleblower's claim. COVID-19 has infected more than 1,444,000 people worldwide and over 83,000 have died. In the midst of this devastation, Trump also fired another inspector general responsible for COVID-19 oversight. By the time this book is 
published, these numbers will have increased exponentially, and our government will not have the independent, inspector general oversight we once had. The light on government is dimming. My August 2018 Freedom of Information Act request regarding religious exemptions from providing health care in hospitals remains unanswered. Is the subject of religious discrimination against ill transgender people still relevant in the face of a pandemic? Consider this. Refusing, on religious grounds, to treat patients with COVID-19, be they transgender patients or not, runs the risk of spreading the virus, sickening thousands and killing thousands, including health care providers and other first responders. We must ask ourselves, "Is helping to spread disease at home and abroad a religious practice protected under the US Constitution? Does the government have a compelling interest in protecting the health of its citizens? If so, why did President Trump fire the inspector general (otherwise known as "watchdog") tasked with overseeing how money would be spent to deal with COVID-19? Without a world government, do citizens of the world have an ethical duty to protect one another? Is President Trump's threat to defund the World Health Organization (WHO) a prudent move?" Our health care landscape is changing radically and dramatically. The US military has been deployed to build massive temporary hospitals on military ships, in parks, barracks, and convention centers. The New York National Guard was ordered to seize ventilators from private hospitals. Cruise ships have offered to turn their vehicles into makeshift hospitals. States are competing against each other for resources. States are competing against the federal government for resources. We are buying ventilators from China. Taiwan is donating masks. Morgues are public charnel grounds. Our economies are devastated. Pandemic health care is a very public, global matter that requires the attitude of universalism, not religious exemptions. May this universalist attitude, embodied in the best of our chaplains, pastoral counselors, and other spiritual caregivers, our Compassion Corps, inform and transform our movements toward hospitality, co-habitation, empathy, compassion, loving kindness, nondiscrimination, religious freedom law literacy, and human rights advocacy.

\section{Notes}

1. Sullivan, 126.

2. Nhat Hanh, Present Moment, Wonderful Moment, 3.

3. Jake Bradley and Nate Metrick, email message to author, January 29, 2019. 